DOI: 10.31866/2410-1311.37.2021.236002

УДК 784.1:7.071.2Городовенко(477:71)

\title{
- ТВОРЧА ДІЯЛЬНІСТЬ НЕСТОРА ГОРОДОВЕНКА В УКРАЇНІ ТА ЗА КОРДОНОМ
}

\section{- Турчак Леся Іванівна}

- Кандидат мистецтвознавства, доцент, ORCID: 0000-0002-0490-8732, e-mail: lessit@ukr.net, Київський національний університет культури і мистецтв, вул. Є. Коновальця, 36, Київ, Україна, 01133

\section{- Для цитування:}

Турчак, Л.І. (2021). Творча діяльність Нестора Городовенка в Україні та за кордоном. Питання культурологіï, (37), 80-92. doi: https://doi.org/10.31866/2410-1311.37.2021.236002.

\section{Анотація}

Мета статті - з'ясувати внесок Нестора Городовенка в музичне мистецтво не лише України, а й у світову культуру. Методологія дослідження ґрунтується на принципах системності та історизму. У статті використано методи наукового дослідження, серед яких дослідницько-пошуковий та джерелознавчий, системно-аналітичний, біографічний та метод типологічного аналізу, а також культурологічні й мистецтвознавчі теорії та розробки (теорія сучасного хорового мистецтва, теорія інтерпретації). Наукова новизна полягає у дослідженні творчої діяльності педагога, громадського діяча, хормейстера Н. Городовенка з акцентом на популяризацію національно-пісенної спадщини та хорової музики українських композиторів. Висновки. Проаналізовано творчий шлях Н. Городовенка і доведено, що попри відсутність спеціальної музичної освіти, маестро, опираючись на пісенну практику українського народу, власний талант і музичну самоосвіту, зміг розвинути і презентувати українське хорове мистецтво як в Україні, так і за її межами. Його творча діяльність за кордоном допомагала зберегти національну і культурну ідентичність та знайомити світ із українською культурою та мистецтвом. Зауважимо, що попри грандіозні успіхи за кордоном, в УРСР про тріумфи й здобутки хору і хормейстера інформації не було. Своєю діяльністю він популяризував національно-пісенну спадщину та хорову музику українських композиторів. Виявлено, що серед вагомих здобутків Н. Городовенка успішна діяльність керованих ним колективів; розвиток української хорової музики; виконання європейської духовної музики; творча діяльність у мистецькому середовищі української діаспори Канади у 50-60-х рр. XX ст. 3'ясовано, що авторська методика творчої діяльності Н. Городовенка $є$ вагомим внеском у розвиток і інтерпретацію української народної пісні, популяризацію хорової музики та української культури.

Ключові слова: Нестор Городовенко; творча діяльність; хорове виконавство; капела «Думка»; хор «Україна»; українська народна пісня 


\section{- Вступ}

Події першої половини XX ст. виявилися складними для розвитку культури, мистецтва, науки та змусили багатьох митців залишити рідний край. Багато з них отримали визнання далеко за ії межами, а їх творчість вплинула на розвиток як українського, так і світового мистецтва. Однак виявилось, що досліджень, присвячених творчості українців за кордоном, не так уже й багато.

В українській культурології дослідження хорового співу залишається актуальним, ще й тому, що чимало спеціальних досліджень, присвячених диригентсько-хоровому мистецтву, хибують на надмірну описовість і так званий чистий вигляд, коли різні аспекти, «аналізуються ніби у вакуумі, без залучення широкого контексту гуманітарних сфрер діяльності людини» (Пучко-Колесник, 2009 , с. 5). Водночас залишається ряд невирішених проблем, що стосуються хорового мистецтва та його місця в музичній культурі.

Мистецтвознавство $€$ наукою «з людським обличчям», уособленим (персоніфрікованим) знанням, а тому одним із пріоритетних напрямів дослідження $€$ аналіз життєтворчості видатних діячів української культури загалом і хорового мистецтва зокрема. У цьому контексті актуальним постає нове розуміння історії українського хорового мистецтва, вагомою сторінкою якого є життя та творчість представника київської школи хорового виконавства - Нестора Феофрановича Городовенка (1885-1964).

Творчість Н. Городовенка тривалий час залишалась поза увагою наукової спільноти. I хоча час від часу з'являлися поодинокі публікації спогадів чи статті оглядового й довідникового характеру, однак комплексного дослідження не проводилося. Новим етапом в історії вивчення життєвого та творчого шляху українського диригента виявились роботи Г. Шибанова (2001; 2007), який відкрив творчість Н. Городовенка по-новому. I досі більшість статей ґрунтуються на розвідках Г. Шибанова, переповідаючи окремі факти та події з життя маестро (Чернов, 2014; Петрич, 2019). Виключення становлять роботи І. Парфентьєвої (2011) про музично-педагогічні аспекти та Г. Карась (2020), які розкривають культуротворчі та історико-генетичні аспекти діяльності українського митця. У монограффії Г. Карась (2012) презентовано напрям - українське музичне діаспорознавство (Ucrainica musica diasporiana).

\section{- Мета статті}

Мета статті полягає у виявленні внеску Н. Городовенка в музичне мистецтво не лише України, а й у світову культуру. Методологія дослідження ґрунтується на принципах системності та історизму. У статті використано методи наукового дослідження, серед яких дослідницько-пошуковий та джерелознавчий, системно-аналітичний, біографічний та метод типологічного аналізу, а також культурологічні й мистецтвознавчі теорії та розробки (теорія сучасного хорового мистецтва, теорія інтерпретації). Наукова новизна полягає у дослідженні творчої діяльності педагога, громадського діяча, хормейстера Н. Городовенка з акцентом на популяризацію національно-пісенної спадщини та хорової музики українських композиторів. 


\section{- Виклад матеріалу дослідження}

Народився Нестор Феофанович Городовенко 9 листопада (27 жовтня - за старим стилем) 1885 р. в селі Венслави Лохвицького району на Полтавщині. Під час навчання у початковій школі співав у церковному хорі. Після закінчення двокласного училища, в шістнадцять років вступив до Полтавської учительської семінарії (1901-1903), де, за словами дослідника Г. Завітневича (1993), окрім загальноосвітніх і спеціальних педагогічних предметів, «в ній були добре організовані музичні курси, на яких викладали елементарну теорію музики, основи гармонії, диригування хором і спів» (с. 23). І уже на третьому курсі Н. Городовенко почав працювати з хором під керівництвом Івана Різенка, від якого перейняв манеру диригування. Закінчивши навчання в семінарії, один рік працював вчителем у селі на Полтавщині, а згодом вступив до Глухівського вищого вчительського інституту (1907), де брав уроки у професора Петербурзької консерваторії Олександра Івановича Рубця.

З 1907 по 1916 рр. керував хорами в навчальних закладах та церквах у Лохвиці, Переяславі, Ольгополі (на Вінниччині). Створював учнівські аматорські хори. Працюючи при Народному домі в Лохвиці Н. Городовенко згадував: «Це, мабуть, був один із тих хорів, у який я вклав увесь запал, усю любов і екзальтацію та водночас багато навчився в інтерпретації народної пісні, бо співаки так правдиво й безхитрісно робили нюанси, що від пісні завжди пахло землею і віковими традиціями українського села» (Петрич, 2019).

У 1917 р. Н. Городовенко приїхав до Києва, працював у Другій гімназії, де присвятив себе виключно диригентській діяльності. Тут він познайомився з видатними майстрами українського хорового мистецтва М. Леонтовичем, К. Стеценком, О. Кошицем, Я. Степовим (Парфентьєва, 2011, с. 144). Потім керував хором П'ятої піхотної школи, зведеним хором Всеукраїнської вчительської спілки, паралельно читав лекції з методики співу у Вищому інституті народної освіти (Київський університет). У 1920 р. Н. Городовенко отримав запрошення очолити капелу «Думка» (Державна українська мандрівна капела) (Чернов, 2014).

її коріння сягає любительського хору «Дніпросоюзу» (1918-1919) (Семенко Л., Нікітюк О.). Ідею створення саме мандрівної, просвітницької хорової капели подав тодішній керівник хорової секції «Дніпросоюзу», працівник Міністерства освіти УНР К. Стеценко. Однак, як справедливо зазначає Л. Пархоменко, Нестор Феофанович виявився спритнішим за інших тодішніх мистецьких діячів і зміг під час зміни влади зареєструвати капелу. I уже за більшовиків мета мандрівної просвітницької капели, задуманої К. Стеценком, розвернулася в бік пропаганди радянської влади і просвітництва робочих мас і «трудящих усього Радянського Союзу» (Нікітюк, 2018, с. 496-503).

Однак стверджувати, що капела виступала виключно для пропаганди радянської влади не можна, адже ії̈ репертуар охоплював народні пісні, твори українських композиторів (М. Леонтовича, М. Вериківського та ін.). На думку І. Парфентьєвої (2011), в історії українського хорового мистецтва капела досягла вершин майстерності виконання української пісні. Успіх був зумовлений трьома чинниками: патріотичним ентузіазмом, породженим надіями і подіями українського національного відродження, складом хору і талантом диригента. 
Диригент ставив високі вимоги до професійної діяльності виконавців. Колектив здійснював свою діяльність як антитеза першому Українському національному хору О. Кошиця, який опинився через політичні причини в еміграції.

З огляду на численні критичні публікації, в яких громадськість дорікала капелі у тому, що ії репертуар був національно обмежений, і спів тематичних циклів, таких як колядки і щедрівки та «Музика до Кобзаря» М. Лисенка не відображали життя народу. 1924 року прослідковувалась нова лінія у роботі капели, пов'язана з ідеєю критичного переосмислення культурної спадщини. У репертуарі «Думки» з'явилась музична класика (Парфентьєва, 2011, с. 144).

Ювілейний п'ятий рік її творчої діяльності був відзначений виступами на Чернігівщині, у Києві, Краснодарі, Азербайджані та Грузії. Близько 500 творів входило до репертуару капели: від народних мотивів до творів українських, радянських й західноєвропейських класиків, з-поміж яких фрінал Дев'ятої симфонії Л. Бетховена, «Реквієм» Д. Верді, ораторія Й. Гайдна «Пори року» та ін. (Ткаченко, б.р.).

Впродовж 1926-1929 рр. капела на чолі з Н. Городовенком досягала апогею свого мистецького розвитку та вважалася найкращим хором СРСР. Підтвердженням цього стала поїздка колективу (6 січня 1929 р.) у Францію. До програми концертів входили твори світових класиків, українських композиторів і народні пісні. Окрему увагу критики звернули не лише на якість голосів й емоційність виконання, але й на те, з якою витонченою чутливістю хор сприймав вимоги диригента. Зі слів відомого диригента Ернста Ансерме, який згадував концерт колективу в паризькому залі Плейеля (salle Pleyel), що вважається одним із самих великих залів XX ст., особливе захоплення у французької публіки викликала басова партія «Думки»: «...у нас у Франції немає хору, здатного інтерпретувати так, як цей хор, будь-який величний твір Баха чи Гайдна... чоловічі голоси незрівнянно вищі всього того, що можна почути в нас. Тільки Україна має баси, здатні сягнути такої глибини...» (Парфентьєва, 2011, с. 145). В одній із публікацій Чернова (2014) є відгук О. Кошиця стосовно виступу колективу, в якому він зазначав: «Українська пісня в їх виконанні викликала здивування, обожнювання і шалене захоплення цілого світу». Виступ у Франції, позитивні відгуки як іноземців, так і відомих українців свідчать про гідну презентацію українського мистецтва у Європі.

Завдяки виконанню «Дударика», «Щедрика» М. Леонтовича, «Колискової» М. Вериківського, «Коляди» П. Козицького та інших шедеврів української хорової класики, високому професійному рівню «Думка» отримала популярність, а чимало співаків (3. Гайдай, В. Гутова, І. Тоцький, М. Платонова, Ю. Лозинський, Б. Златогорова, О. Колуб, С. Данченко та ін.) підвищили свою мистецьку майстерність й стали згодом зірками оперних театрів України (Ткаченко, б.р.).

311 по 21 серпня 1936 р. капела разом з кращими творчими колективами УРСР взяла участь у Декаді українського мистецтва в Москві. «Думка» презентувала все багатство хорової культури українського народу: «А вже весна», «Ой наступила та чорна хмара», «Туман яром котився» М. Лисенка; «Закувала та сива зозуля» О. Ніщинського; «Чорноморець», «Розпрягайте, хлопці коні» П. Демуцького; «Дударик», «Щедрик» М. Леонтовича; «Ченчик» О. Кошиця тощо. Виступи пройшли успішно, а Н. Городовенко нагороджено орденом «Знак Поша- 
ни» (орден був заснований Постановою ЦВК СРСР від 25 листопада 1935 року для нагородження за високі досягнення у виробництві, науково-дослідній, державній, соціально-культурній, спортивній й іншій суспільно корисній діяльності) (Чернов, 2014).

1930-ті роки виявилися нелегкими для колективу та позначилися на творчій роботі Н. Городовенка. Попри великий успіх концертів у Києві, Харкові, Запоріжжі, на Одещині, Чернігівщині та присвоєння звання Заслуженої державної капели, в СРСР розпочався так званий наступ на хорову музику, яку почали вважати «церковщиною», заборонили класичні твори, проходили «чистки» хористів та хормейстерів з огляду на їхнє «сумнівне соціальне походження», що, врешті решт, призвело до масової ліквідації аматорських й професійних колективів (Чернов, 2014).

В цей період «Думка» мала обмежений репертуар, у якому переважали пісні революційно-агітаційної тематики, кантатно-ораторіальні твори (Крупина \& Камінська, 2004). Постійні втручання у підбір репертуару, що призвели до його звуження та виконання «пропагандистського сміття», неабияк дратували Н. Городовенка, який на той час вже був професором Київського музично-драматичного інституту імені М. Лисенка. Його опір цим процесам призвів до того, що диригента усунули від роботи й керування капелою (Чернов, 2014). Дослідники зауважують, що причиною звільнення могла послугувати зустріч із Й. Сталіним. Оскільки 1936 р. відбувся виступ «Думки» на Декаді українського мистецтва в Москві, на якому був присутній Сталін, після виступу хормейстера позбавили роботи (Шибанов, 2001; Карась, б.р.).

Безпідставне звільнення Городовенка у 1936 р. (у деяких джерелах 1937 р.) за вказівкою директивних органів (НКВС) з посади головного диригента капели стало для нього травмою, він певний час залишався без роботи. Через рік його призначили на посаду керівника вокальної групи створеного Ансамблю пісні і танцю УРСР, хореографічною групою якого керував П. Вірський. За досить короткий термін хормейстер підняв виконавство колективу на високий рівень, що той міг конкурувати 3 «Думкою».

На початку Другої світової війни колектив евакуювали до Харкова, а згодом — на Північний Кавказ, де було продовжено гастролі. У 1942 р. Городовенко повернувся до Києва і отримав посаду другого хормейстера (після П. Гончарова) хорового колективу Української національної хорової капели. Під час роботи на цій посаді він здебільшого звертався до «духовних композицій» українських композиторів. У серпні 1943 р. капела під його керівництвом дала останній великий концерт у Києві, в програмі якого були хорові концерти Д. Бортнянського та А. Веделя (Парфентьєва, 2011, с. 145). Того ж року Н. Городовенко переїхав до Львова, де з ініціативи Інституту народної творчості у листопаді очолив Український національний хор імені М. Леонтовича. У своєму репертуарі цей колектив мав класичні, народні та духовні твори (Парфентьєва, 2011, с. 145).

Обставини складались так, що часу для стабільної роботи хору не залишалося. Влітку 1944 року почались щоденні бомбардування м. Львів, подальше перебування тут було небезпечним. У липні 1944 р. диригент з хором емігрував до Німеччини, де перебував у таборах для переміщених осіб (Шибанов, 
2007, с. 17). I вже у грудні 1945 р., у таборі містечка Фюссен він організував хор «Україна», який став згодом відомим у Західній Німеччині не в останню чергу завдяки тому, що Н. Городовенко «...доповнив свою групу таборовими співаками і створив сильний здисциплінований хор і з ним, поза виступами в таборі, peпрезентував українську культуру релігійними концертами в німецьких костелах» (Рогатинський, 2001, с. 15).

В репертуарі була українська класика, твори Д. Бортнянського, О. Кошиця, К. Стеценка, а також народні пісні в обробці композиторів. Городовенко із своїм хором проводив по два концерти (один із творів української та зарубіжної хорової класики, а другий - духовний) й ставив перед собою мету — популяризувати українське хорове мистецтво у Західній Європі, наслідуючи справу Олександра Кошиця (Карась, б.р., с. 53).

Репертуар «України» нараховував близько 500 творів. Німецька преса та публіка, знамениті диригенти й композитори висловлювали свою пошану. Один з них у «Золотій книзі», до якої адміністрація хору вносила усі коментарі, написав наступне: «Не буду говорити вам детально, дорогі друзі, про ваш спів. Хочу нагадати коротко. Це була музика, яка мала силу грому і ніжність зефіру. Це був вулкан, який на своїй дорозі не мав стриму, він плив аж до крайнього зомління, щоб знову вибухнути ще з більшою силою громів і вогню...» (Кульчицький, 1961, с. 28). Заразом, як зазначає Г. Шибанов, справжнім тріумфом хору Н. Городовенка були його концерти під час Тижня української культури в Мюнхені і Франкфурті у 1948 р., коли він з великим успіхом виступав спільно з Капелою бандуристів імені Т. Шевченка (Шибанов, 2001, с. 160). На жаль, не зважаючи на такий успіх за кордоном, в Україні про тріумфии і здобутки хору і хормейстера не було інфрормації. Хоча Н. Городовенко й популяризував українське хорове мистецтво, представлене в репертуарі хору «Україна» творами О. Кошиця, М. Леонтовича, К. Стеценка, Я. Степового, П. Демуцького, В. Барвінського, С. Людкевича та ін. Хор також виконував хорові композиції зарубіжних класиків та здійснив вагомий внесок у взаємозбагачення німецької та української культур (Шибанов, 2007 , с. 17). Зокрема український етнограф, письменник, фрольклорист О. Воропай, який зустрічався з диригентом у Німеччині, зазначав, що той з енергією щоразу брався до роботи. Спільно з поетом І. Багряним, маляром-монументалістом М. Дмитренком та іншими діячами брав активну участь у налагодженні українського культурно-мистецького життя. О. Соневицька, бувши спочатку слухачем виступів капели у Міттенвальді, а згодом її членом, акцентувала на важливих аспектах хормейстерської майстерності Н. Городовенка: на репетиціях панувала зразкова дисципліна та абсолютна тиша; перед вивченням твору диригент обов'язково пояснював його зміст й демонстрував тон, що він його вимагав від виконавців (Соневицька, 2008, с. 347-348).

Попри визначні успіхи капели, життя митця у Німеччині було небезпечне, за ним полювала радянська контррозвідка в Тюрингії. Йому та ще низці співаків довелося змінювати прізвища на кілька років. «І тільки перебравшись завдяки американській військовій адміністрації до Фюссена (Баварія), де хорові було надано фінансову підтримку від німецької влади, Н. Городовенко отримав можливість працювати в кращих умовах» (Шибанов, 2007, с. 16). 
Наприкінці 1948 р. диригент отримав запрошення від Українського національного об'єднання (УНО) Канади. Саме там він створив при УНО хор «Україна», яким керував майже п'ятнадцять років (Карась, б.р, с. 53). Враховуючи те, що колектив був аматорським, Н. Городовенку, для того, щоб досягнути з ним високого мистецького рівня, довелося наполегливо та багато працювати (Шибанов, 2007, с. 19).

Свій перший концерт «Україна» під керівництвом Н. Городовенка дала на Шевченківській академії в березні 1949 р. в залі на Плато Голл, де українська культурна громада міста організовувала різні урочистості. Концерт пройшов з успіхом і багато пісень, а це твори М. Лисенка (на поезії Т. Шевченка), пісенні обробки М. Леонтовича, П. Демуцького та інших українських композиторів, у Канаді прозвучали вперше. Слухачів хор вразив не лише кількісним складом, але й майстерним і неповторним виконанням української пісні. Наголошуючи на тому, що хормейстер представив канадським слухачам усе багатство хорового репертуару, накопичене ним за всі роки творчої діяльності, Г. Шибанов слушно зазначає: «Своєю невтомною творчою діяльністю Нестор Феофанович намагався підкреслити українську присутність у Канаді, широко популяризуючи пісенну та хорову спадщину нашого народу» (Шибанов, 2007, с. 20).

За роки праці диригента з хором, «Україна» здобула популярність не лише в Монреалі, а й в інших містах Канади. До репертуару хору входило близько 500 творів зарубіжних та українських композиторів, які підкреслювали високу майстерність колективу, що була досягнута й працею Н. Городовенка. Також його спів записувався й поширювався на платівках, які випускало УНО. Музейним раритетом нині вважається альбом із шести платівок, на яких записано перлини української хорової класики (твори М. Леонтовича, П. Демуцького, О. Кошиця, К. Стеценка, С. Людкевича), що їх виконував хор (Шибанов, 2007, с. 22).

1956 року маестро не зміг порозумітися з керівництвом фрілії УНО в Монреалі, у зв'язку з цим деякий час працював диригентом хору одного з найбільших православних храмів Канади - собору Св. Софії. Хор під керівництвом Городовенка збагатив свій репертуар духовними творами Д. Бортнянського, О. Кошиця, К. Стеценка, П. Гончарова (Шибанов, 2007, с. 23). Однак згодом він повернувся до роботи з хором «Україна».

Останній виступ Н. Городовенка зі своїм колективом на сцені філії УНО відбувся навесні 1963 р. Концерт пройшов з успіхом, а переповнена зала аплодувала у відповідь на нові мистецькі грані, які разом з хором розкрив маестро згадував колишній співак хору «Україна» І. Стельмащук 10 березня 1998 р. (зберігаються в особистому архіві Г. Шибанова).

Помер Нестор Городовенко 21 серпня 1964 р. у «Конвеленсент шпиталі» на околиці Монреаля. Похований на цвинтарі Монт-Роял. На скромному граніті викарбувані слова: «Свою Україну любіть!». У газеті «Новий шлях» УНО у некролозі написано: «Зі смертю Н. Городовенка українська еміграція втратила другого після Кошиця найвидатнішого знавця українського хорового мистецтва» (Шибанов, 2001, с. 208).

У численних публікаціях М. Антоновича, В. Завітневича, Г. Китастого, П. Волиняка, Б. Ковальського та ін. дізнаємося, що у 50-х - на початку 60-х рр. 
Н. Городовенко продовжував популяризувати українську пісню у контексті духовно-мистецького життя української діаспори, про що зокрема М. Антонович відзначав, що маестро був непересічною особистістю та великим життєлюбом та підкреслював, що не всі в Канаді розуміли масштаб й значення його мистецького подвижництва, від чого той дуже страждав (Шибанов, 2007, с. 23). У лекціях з історії вокально-хорового виконавства Г. Карась (б.р.) називає Н. Городовенка «носієм українського національного звукового ідеалу», який, як і О. Кошиць, працював в найбільш поширеному у професійному хоровому виконавстві напрямі академічного співу. Цей напрям, за словами С. Казачкова, передбачає благородство смаку, значущість змісту, високу досконалість форми, одухотвореність дотримання традицій. «Всяка жива система, живий організм поєднують в собі дві тенденції: охоронно-консервативну і оновлююче-революційну. Наявність в академічному хорі першої тенденції не заважає другій здійснювати свою розвивальну функцію» (Казачков, 1982, с. 43). І ця функція у творчій особистості Н. Городовенка проявилася на рівні яскравої диригентської інтерпретації, за якою стоїть відчуття стилю й проникнення у сутність художніх образів виконуваних творів.

\section{- Висновки}

Отже, Нестор Феофанович Городовенко хоча й не отримав спеціальної музичної освіти, однак його талант та любов до України свідчили не лише про високий професійний рівень митця, але й сприяли популяризації народної пісні, хорової музики та української культури на світовому рівні.

Його школа - це пісенна практика рідного народу та музична самоосвіта. Маестро розробляв виконання автентичних народних пісень й презентував національно-пісенну спадщину, сформував оригінальний напрям розвитку хорової музики українських композиторів як в Україні, так і за кордоном. У звучанні керованих ним колективів був відчутний вплив народно-співочих традицій, адже саме вони є носіями української виконавської церковно-хорової традиції. Долучався Н. Городовенко й до формування української оригінальної хорової музики, «першопрочитання» і виконання європейської духовної музики, піднесення її рівня до європейських капел того часу.

Демонструючи найкращі досягнення української диригентсько-хорової школи, хормейстер направив свій талант на популяризацію найкращих зразків хорової класики, української народної пісні та духовної музики, що спричинило значні успіхи очолюваних маестро хорових колективів, особливо за кордоном.

Відзначимо, що Н. Городовенко брав участь у відродженні хорового руху України 1920-х років, ставши одним із фундаторів київської школи хорового виконавства, здійснював просвітницьку діяльність у духовно-мистецькому середовищі української діаспори Канади в 50-60-х роках, що свідчить не лише про масштабність його творчої особистості, але й духовний зв'язок з Батьківщиною. I попри вимушену еміграцію та небезпеку для життя, оскільки за ним полювала радянська контррозвідка, Н. Городовенко завжди залишався вірним сином України. Його творча діяльність за кордоном допомагала зберегти національну і культурну ідентичність та знайомити світ із українською культурою та мисте- 
цтвом. Зауважимо, що попри грандіозні успіхи за кордоном, в УРСР про тріумфи і здобутки хору і хормейстера інформації не було.

Нестор Феофанович Городовенко, володіючи благородством смаку, відчуттям стилю й проникненням у сутність художніх образів, високою досконалістю форми та одухотвореністю дотримання традицій, безмежно любив Україну. Навіть на гранітному обеліску (цвинтар Монт-Роял, Монреаль), де похований маестро, викарбувані слова: «Свою Україну любіть!». Тож Нестор Феофанович Городовенко справедливо посідає почесне місце серед плеяди найвидатніших українських та світових митців XX ст.

\section{- Список використаних джерел}

Бенч, О. (2002). Павло Муравський. Феномен одного життя [Монографія]. Дніпро.

Завітневич, Г. (1993). Нестор Городовенко. Музика, 5, 22-24.

Казачков, С. (1982). Сегодняшний день хоровой культуры. Советская музыка, 2, 42-45.

Карась, Г. (2012) Музична культура української діаспори у світовому часопросторі $X X \mathrm{~cm}$. Тіповіт.

Карась, Г. (2020). Культуротворча діяльність українських хорових диригентів в умовах таборів Ді-Пі після Другої світової війни. Народна творчість та етнологія, 1(383), 23-36.

Карась, Г. (б.р.). Історія вокально-хорового виконавства. Взято 24 серпня 2020 3 http://194.44.152.155/elib/local/3689.pdf

Крупина, В., \& Камінська, Г. (2004). Думка. В В. А. Смолій (Ред.), Енциклопедія історії України (Т. 2: Г-Д). http://www.history.org.ua/?termin=Dumka

Кульчицький, М. (1961). Духовні концерти Н. Городовенка (спогад). Київ (Філадельфія), 1(64), 26-30.

Нікітюк, О. П. (2018). Капела "Думка" в контексті національного хорового руху 1917-1920-х років. Мистеитвознавчі записки, 33, 496-503.

Парфентьєва, І.П. (2011). Музично-педагогічна діяльність Нестора Городовенко (на прикладі вивчення творів А. Веделя). Науковий вісник Миколаївського державного університету імені В. О. Сухомлинського. Педагогічні науки, 1(33), 143-146.

Петрич, О. (2019, 11 червня). Геній хорового співу (до 55-річчя з дня смерті Нестора Городовенка). Новини Лохвиччини. https://news.com.ua/news/3248-henijkhorovoho-spivu-do-55-richchia-z-dnia-smerti-nestora-horodovenka/

Пучко-Колесник, Ю. В. (2009). Діяльність диригента-хормейстера як соціокультурний френомен [Автореферат дисертації кандидата мистецтвознавства, Національна музична академія України ім. П. І. Чайковського].

Рогатинський, П. (Ред.). (2001). Міттенвальд 1946-1951. 3 нагоди 50-ліття таборів українських біженців у Міттенвальді, Німеччина. Воррен. Мічиган.

Соневицька, О. (2008). Нестор Городовенко у моїх спогадах. В І. Лисенка (Ред.), Музична культура України у спогадах, матеріалах, листах (с. 346-348). Рада.

Соневицький, І. (1955, 3 червня). Маестро. Свобода, 105.

Сушко-Наконечна, О. (1997). Про Нестора Городовенка. Нові дні, 6, 29-31.

Ткаченко, Н.М.(б.р.). Діяльність першої державної української мандрівної капели "Думка" як фоктор збереження національно-культурного простору в Україні 
в 20-30-ті роки XX сторіччя. Новий Акрополь. Культурна асоціація. Взято 20 вересня 2020 з https://newacropolis.org.ua/theses/998c28ce-d904-4c44-8802c91b6d28f5be

Чернов, А. (2014, 5 вересня). Поліфонія української пісні. Дзеркало тижня, 31. https:// zn.ua/ukr/personalities/polifoniya-ukrayinskoyi-pisni-_.html

Шибанов, Г. (2001). Нестор Городовенко. Життя і творчість. Видавництво імені Олени Теліги.

Шибанов, Г. (2007). Хормейстерська діяльність Нестора Городовенка в Канаді. Студії мистецтвознавчі, 2(18), 16-25.

\section{References}

Bench, O. (2002). Pavlo Muravskyi. Fenomen odnoho zhyttia [Pavlo Muravskyi. The Phenomenon of one Life] [Monograph]. Dnipro [in Ukrainian].

Chernov, A. (2014, September 5). Polifoniia ukrainskoi pisni [Polyphony of Ukrainian song]. Dzerkalo Tyzhnya, 31. https://zn.ua/ukr/personalities/polifoniya-ukrayinskoyi-pisni-_. html [in Ukrainian].

Karas, G. (2012) Muzychna kultura ukrainskoi diaspory u svitovomu chasoprostori XX st. [Musical Culture of the Ukrainian Diaspora in World of the $20^{\text {th }}$ Century]. Tipovit [in Ukrainian].

Karas, G. (2020) Kulturotvorcha diialnist ukrainskykh khorovykh dyryhentiv v umovakh taboriv Di-Pi pislia Druhoi svitovoi viiny [Cultural activity of Ukrainian choral conductors in the conditions of DP camps after the Second World War]. Folk Art and Ethnology, 1(383), 23-36 [in Ukrainian].

Karas, G. (n.d.). Istoriia vokalno-khorovoho vykonavstva [History of Vocal and Choral Performance]. Retrieved August 24, 2020, from http://194.44.152.155/elib/local/3689. pdf [in Ukrainian].

Kazachkov, S. (1982). Segodnyashniy den' khorovoy kul'tury [Today is the day of choral culture]. Sovetskaya Muzyka, 2, 42-45 [in Russian].

Krupyna, V., \& Kaminska, H. (2004). Dumka [Opinion]. In V. A. Smolii (Ed.), Entsyklopediia istorii Ukrainy [Encyclopedia of the History of Ukraine] (Vol. 2: G-D). http://www. history.org.ua/?termin=Dumka [in Ukrainian].

Kulchytsky, M. (1961). Dukhovni kontserty N. Horodovenka (spohad) [Spiritual concerts of N. Horodovenko (memory)]. Kyiv (Philadelphia), 1(64), 26-30 [in Ukrainian].

Nikitiuk, O. P. (2018) Kapela "Dumka" v konteksti natsionalnoho khorovoho rukhu 1917-1920-kh rokiv [Dumka Choir in Context of National Choral Movement in 1917-1920s.]. Notes on Art Criticism, 33, 496-503 [in Ukrainian].

Parfentieva, I. P. (2011). Muzychno-pedahohichna diialnist Nestora Horodovenko (na prykladi vyvchennia tvoriv A. Vedelia) [Musical and pedagogical activity of Nestor Horodovenko (on the example of studying the works of A. Wedel)]. Scientific Herald V.O. Sukhomlynskyi National University of Mykolaiv. Pedagogical Sciences, 1(33), 143-147 [in Ukrainian].

Petrich, O. (2019, June 11). Henii khorovoho spivu (do 55-richchia z dnia smerti Nestora Horodovenka) [Genius of Choral Singing (to the $55^{\text {th }}$ Anniversary of the Death of Nestor Horodovenko)]. Novyny Lokhvychchyny. https://Inews.com.ua/news/3248-henijkhorovoho-spivu-do-55-richchia-z-dnia-smerti-nestora-horodovenka/ [in Ukrainian]. 
Puchko-Kolesnik, Yu. V. (2009). Diialnist dyryhenta-khormeistera yak sotsiokulturnyi fenomen [The Activity of a Conductor-choirmaster as a Socio-cultural Phenomenon] [Abstrakt of PhD Dissertation, National Music Academy of Ukraine named after P. I. Chaikovsky] [in Ukrainian].

Rohatynskyi, P. (Ed.). (2001). Mittenwald 1946-1951. Z nahody 50-littia taboriv ukrainskykh bizhentsiv u Mittenvaldi, Nimechchyna [Mittenwald 1946-1951. On the Occasion of the $50^{\text {th }}$ Anniversary of the Ukrainian Refugee Camps in Mittenwald, Germany]. Warren. Michigan [in Ukrainian].

Shibanov, G. (2001). Nestor Horodovenko. Zhyttia i tvorchist [Nestor Horodovenko. Life and Work]. Vydavnytstvo imeni Oleny Telihy [in Ukrainian].

Shibanov, G. (2007). Khormeisterska diialnist Nestora Horodovenka v Kanadi [Nestor Horodovenko's Choir Leading Work in Canada]. Researches of the Fine Arts, 2(18), 16-25 [in Ukrainian].

Sonevytskyi, I. (1955, June 3). Maestro [Maestro]. Svoboda, 105 [in Ukrainian].

Sonevytska, O. (2008). Nestor Horodovenko u moikh spohadakh [Nestor Horodovenko in my memories]. In I. Lysenko (Ed.), Muzychna kul'tura Ukrayiny u spohadakh, materialakh, lystakh [Musical Culture of Ukraine in Memoirs, Materials, Letters] (pp. 346-348). Rada [in Ukrainian].

Sushko-Nakonechna, O. (1997). Pro Nestora Horodovenka [About Nestor Horodovenko]. Novi dni, 6, 29-31 [in Ukrainian].

Tkachenko, N. M. (n.d.). Diialnist pershoi derzhavnoi ukrainskoi mandrivnoi kapely "Dumka" yak faktor zberezhennia natsionalno-kulturnoho prostoru v Ukraini v 20-30-ti roky XX storichchia [The Activity of the First State Ukrainian Traveling Chapel "Dumka" as a Factor in Preserving the National and Cultural Space in Ukraine in the 2030s of the Twentieth Century]. Novyi Akropol. Kulturna asotsiatsiia. Retrieved September 20, 2020, from https://newacropolis.org.ua/theses/998c28ce-d904-4c448802-c91b6d28f5be [in Ukrainian].

Zavitnevich, G. (1993). Nestor Horodovenko [Nestor Horodovenko]. Muzyka, 5, 22-24 [in Ukrainian].

\section{- NESTOR HORODOVENKO'S CREATIVE WORK IN UKRAINE AND ABROAD}

\section{- Lesia Turchak}

- PhD in Art Studies, Associate Professor,

ORCID: 0000-0002-0490-8732, e-mail: lessit@ukr.net,

Kyiv National University of Culture and Arts,

Kyiv, Ukraine

\section{- Abstract}

The purpose of the article is to define Nestor Horodovenko's contribution not only to the music art of Ukraine but also to world culture. The research methodology is based on the principles of consistency and historicism. The following methods of scientific research are 
applied in the article: research and searching, source studies, system-analytical, biographical, and typological analysis, as well as cultural and art studies theories and developments (theory of modern choral art, theory of interpretation). The scientific novelty lies in the study of the creative work of the teacher, public figure, choirmaster N. Horodovenko with the emphasis on the promotion of the national song heritage and choral music of Ukrainian composers. Conclusions. The article analyses the creative work of N. Horodovenko and demonstrates that despite the lack of special musical education, the maestro, relying on the song practice of the Ukrainian people, his talent and musical self-education, developed and presented Ukrainian choral art both in Ukraine and abroad. His creative work abroad helped to preserve the national and cultural identity and acquaint the world with Ukrainian culture and art. It should be noted that despite the huge success abroad, there was no information about the triumphs and achievements of the choir and choirmaster in the Ukrainian SSR. Through his activities, he popularized the national song heritage and choral music of Ukrainian composers. The successful activity of the choirs led by Horodovenko, the development of Ukrainian choral music, the performance of European sacred music, creative work in the artistic environment of the Ukrainian diaspora of Canada in the 1950s-1960s have been named among N. Horodovenko's significant achievements. The article reveals that the author's method of creative work of $\mathrm{N}$. Horodovenko is a significant contribution to the development and interpretation of Ukrainian folk songs, promotion of choral music and Ukrainian culture.

Keywords: Nestor Horodovenko; creative work; choral performance; chapel "Dumka"; choir "Ukraine"; Ukrainian folk song

\section{ТВОРЧЕСКАЯ ДЕЯТЕЛЬНОСТЬ НЕСТОРА ГОРОДОВЕНКО В УКРАИНЕ И ЗА РУБЕЖОМ}

\section{- Турчак Леся Ивановна}

- Кандидат искусствознания, доцент,

ORCID: 0000-0002-0490-8732, e-mail: lessit@ukr.net,

Киевский национальный университет культуры и искусств,

Киев, Украина

\section{- Аннотация}

Цель статьи - выяснить вклад Нестора Городовенко в музыкальное искусство не только Украины, но и в мировую культуру. Методология исследования основывается на принципах системности и историзма. В статье использованы методы научного исследования, среди которых исследовательско-поисковый и источниковедческий, системно-аналитический, биографический и метод типологического анализа, а также культурологические и искусствоведческие теории и разработки (теория современного хорового искусства, теория интерпретации). Научная новизна заключается в исследовании творческой деятельности педагога, общественного деятеля, хормейстера Н. Городовенко с акцентом на популяризацию национально-песенного наследия и хоровой музыки украинских композиторов. Выводы. Проанализирован творческий путь 
Н. Городовенко и доказано, что несмотря на отсутствие специального музыкального образования, маэстро, опираясь на песенную практику украинского народа, собственный талант и музыкальное самообразование, смог развить и представить украинское хоровое искусство как в Украине, так и за ее пределами. Его творческая деятельность за рубежом помогала сохранить национальную и культурную идентичность и знакомить мир с украинской культурой и искусством. Заметим, что несмотря на грандиозные успехи за рубежом, в УССР о триумфах и достижениях хора и хормейстера информации не было. Своей деятельностью он популяризировал национально-песенное наследие и хоровую музыку украинских композиторов. Выявлено, что среди весомых достижений Н. Городовенко успешная деятельность руководимых им коллективов; развитие украинской хоровой музыки; исполнение европейской духовной музыки; творческая деятельность в художественной среде украинской диаспоры Канады в 50-60-х годах XX в. Выяснено, что авторская методика творческой деятельности Н. Городовенко является весомым вкладом в развитие и интерпретацию украинской народной песни, популяризацию хоровой музыки и украинской культуры.

Ключевые слова: Нестор Городовенко; творческая деятельность; хоровое исполнительство; капелла «Думка»; хор «Украина»; украинская народная песня 